\title{
INFLUENCE OF MULTI-WALLED CARBON NANOTUBES (MWCNT) ON THE STATIC AND HIGH-CYCLE FATIGUE PROPERTIES OF ADHESIVE JOINTS OF 2024-T3 ALUMINIUM ALLOY SUBJECTED TO PEEL
}

\begin{abstract}
Andrzej Kubit
Preliminary communication

The paper presents the results of the research undertaken to determine the impact of the epoxy adhesive nanofiller, in the form of multiwall carbon nanotubes (MWCNT), on the fatigue strength and fatigue lifetime of adhesive joints subjected to peel. Carbon nanotubes were synthesized by means of CVD method with Fe-Co catalysts. Three variants of filled epoxy adhesive were considered, the quantity of $0.5 \mathrm{wt} . \%, 1.0 \mathrm{wt} . \%, 1.5 \mathrm{wt} . \% \mathrm{were}$ used. Such compositions went through the process of mixing, ensuring the adequate nanotubes dispersion. The prepared composition was used to join two adherends made of 2024-T3 aluminium alloy. Adhesive joints underwent high-cycle fatigue peel strength tests with the limit number of cycles of 2 million. The tests were carried out on the electromagnetic vibration inductor with the resonance frequency of the flexible adhesive-joined element of about $600 \mathrm{~Hz}$. For each variant, the fatigue curve and fatigue lifetime were determined for a given level of stress. Thanks to adding carbon nanotubes to epoxy adhesives, the possibility of increasing the fatigue strength by $28.9 \%$ and the fatigue lifetime by about $477.2 \%$ was discovered. The fatigue strength tests were preceded by static T-peel tests.
\end{abstract}

Keywords: adhesives joints; aluminium alloy; carbon nanotubes; fatigue; nanofillers; peel; T-peel test

\section{Utjecaj višestjenih ugljikovih nanocjevčica (MWCNT) na statička i visoko-ciklička svojstva zamora adhezijskih spojeva aluminijske legure 2024-T3 podvrgnute ljuštenju}

Prethodno priopćenje U radu se predstavljaju rezultati istraživanja provedenog u svrhu određivanja utjecaja nanofilera od epoksidnih ljepila u obliku višestjenih ugljikovih nanocjevčica - multiwall carbon nanotubes (MWCNT) na zamornu čvrstoću i vijek trajanja do zamora adhezijskih spojeva podvrgnutih ljuštenju. Ugljikove nanocjevčice su sintetizirane s Fe-Co katalizatorima primjenom CVD metode. Razmatrane su tri varijante primijenjenog epoksidnog ljepila, a upotrjebljene su količine od 0.5 wt.\%, 1.0 wt.\%, 1.5 wt.\%. Takvi su sastavi prošli kroz postupak miješanja, osiguravajući odgovarajuću disperziju nanocjevčica. Pripremljeni se sastav koristio za spajanje dva adherenda napravljena od aluminijske legure 2024-T3. Adhezijski spojevi su podvrgnuti visokocikličkim probama čvrstoće i ljuštenja na zamor s brojem ciklusa ograničenim na 2 milijuna. Probe su izvedene na elektromagnetskom induktoru vibracija s frekvencijom rezonancije fleksibilnog adhezivom spojenog elementa od oko $600 \mathrm{~Hz}$. Za svaku varijantu, krivulja zamora i vijek trajanja do zamora određeni su za datu razinu naprezanja. Zahvaljujući dodavanju ugljikovih nanocjevčica epoksidnim ljepilima otkrivena je mogućnost povećanja zamorne čvrstoće za 28.9 \% i vijeka trajanja do zamora od oko $477.2 \%$. Prije proba čvrstoće na zamor provedene su statičke T-peel probe.

Ključne riječi: adhesijski spojevi; aluminijska legura; ljuštenje; nanofileri; T-peel proba; ugljikove nanocjevčice; zamor

\section{Introduction}

The use of adhesive bonding techniques is becoming more commonly used in the branches of industry that require mass reduction in final products while maintaining high strength and stiffness. One of the greatest advantages of adhesive bonds is their ability to connect different materials while ensuring equal stress distribution in the bond and there are no practical limits to the thickness of the bonded elements. Due to this, these techniques are paramount in joining elements in the aerospace industry. Adhesive bonding in aerospace structures may improve aerodynamics, reduce galvanization corrosion due to isolating qualities of adhesives, and does not create heat affected zones, which is a common problem with welded connections. Besides the many benefits of the aforementioned joining technique, there is a demand for research aiming to improve the practical properties of adhesive joints. In truth, there are no problems in achieving relatively high ultimate strength for joints; however, the problem lies in achieving high durability in adhesive joints, which is dependent on multiple factors related to the properties of the composition of the adhesive and the surfaces of adherends.

The best polymer materials for adhesive bonding, with high cohesive performance, are epoxy resin adhesives. Epoxy resin adhesives are substances of low molecular weight with so-called epoxy function, that is, a three-membered oxirane-ring composed of one oxygen atom linked to two carbon atoms. Among the variety of commercially available epoxy compounds, the most important group of epoxy resins is derived from bisphenol-A. Epoxy resin adhesives are characterized by cohesion strength, long-term durability, and high resistance to ambient conditions and chemicals. Owing to their excellent adhesion properties for metals, mineral surfaces, and wood, they have a wide scope of applications in adhesive technology. Epoxy resin adhesives are cured with primary or secondary diamines. A flexibilizing effect is obtained thanks to the use of longer-chain diamines such as polypropylene glycol diamine, amino-terminated acrylonitrile-butadiene copolymers, and amino amides. Elastic bonds are obtained thanks to the use of polythiols of higher molecular weight [1].

In recent years, conductive-filler-filled polymeric composites have been used for a wide range of applications due to their versatile properties, including thermal stability, mechanical strength, electrical resistance, and adhesive characteristics [2]. Gojny et al. [3] reported that of these composites, the isotropically conductive adhesives (ICAs) filled with organic or inorganic fillers have been investigated as a lead-free 
alternative in microelectronic packaging. A number of techniques have been considered to improve the mechanical properties of structural adhesives containing fillers such as carbon, nylon, or glass micro- or nanofibres. With the passage of time, the manufacturing of modern composites has begun to shift from micro-scale composites to nanocomposites thanks to the use of the unique combination of mechanical and physical properties of nanofillers with a characteristic dimension below 100 $\mathrm{nm}$, especially nanofillers based on carbon nanotubes (CNTs) [4, 5].

Recent studies show that the scientific community is adopting a variety of different methods to develop nanoreinforced composites with varying levels of success. The properties of CNT-based nanocomposites are influenced by a number of factors that include the CNT synthesis and purification process, the geometrical and structural properties of CNTs, their alignment in the matrix, the dispersion process, and the fabrication process $[6,7]$.

The most commonly used engineering materials in aerospace are aluminium alloys due to their wide range of advantages. First of all, they are characterized by a very low density and the ability to transfer loads in load carrying parts, while still being cheaper than other light alloys like those made of titanium and magnesium [8]. Many construction solutions rely on joining of these materials through the use adhesives. There has been a vast amount of research dedicated to various methods of preparing aluminium alloy joints for the static strength of adhesive joints. However, there are few scholarly articles dedicated to the fatigue strength of these bonds. The fatigue strength of a correctly prepared joint depends especially on the type of adhesive as well as load ratio $\mathrm{R}$, the ratio of minimum to maximum value of load.

The authors of the papers [9, 10] revealed that the effect of load ratio has been found to be significant in the fatigue response of polymeric materials. It was observed that increasing the load ratio for a constant maximum fatigue load increased the fatigue life and, conversely, for a constant load range, an increased load ratio had a deleterious influence on the fatigue response [11]. However Crocombe et al. [12] found the effect of frequency on fatigue strength of adhesively bonded joints to be less important.

\section{Materials and methods}

The MWCNTs used in the experiments were produced in the laboratory with the use of the CVD method. To achieve this aim, ethylene, as the source of carbon, was decomposed on the Fe-Co (1:1) catalyst. The nanocrystalline $\mathrm{Fe}-\mathrm{Co}$ catalyst was obtained by coprecipitation of hydroxides starting from a solution of corresponding nitrates and using ammonia water as a precipitating agent. A small amount of calcium and aluminium nitrate was also added to the reaction mixture to reach final concentrations of both $\mathrm{CaO}$ and $\mathrm{Al}_{2} \mathrm{O}_{3}$ of below 3 wt. $\%$ in the catalyst.

The final Fe-Co catalyst was obtained after reduction with hydrogen at $400{ }^{\circ} \mathrm{C}$. After the reduction, the calcium and aluminium oxides remained in the oxide state and played the role of structural promoters of the catalyst, preventing the sintering of small nanocrystallites of cobalt and iron at high temperatures. The addition of such structural promoters was necessary, as the decomposition of ethylene was carried out at $700{ }^{\circ} \mathrm{C}$.

The material obtained after the decomposition of ethylene on the $\mathrm{Fe}-\mathrm{Co}$ catalyst was oxidized in air at 400 ${ }^{\circ} \mathrm{C}$ for $1 \mathrm{~h}$ to remove amorphous carbon and then treated with concentrated hydrochloric acid $(1 \mathrm{M})$ in a microwave-assisted hydrothermal reactor at a pressure of $30 \mathrm{MPa}$ for $1 \mathrm{~h}$ to remove catalyst particles. After the acid treatment, the samples were filtered, washed with distilled water, and dried at $130^{\circ} \mathrm{C}$.

The efficiency of the applied purification method was assessed with the thermogravimetric method using DTAQ600 SDT equipment (TA Instruments). The applied heating rate was $10{ }^{\circ} \mathrm{C} / \mathrm{min}$, starting from room temperature and rising to $900{ }^{\circ} \mathrm{C}$ in air.

The content of metal in the final product was at the level of $3 \mathrm{wt} . \%$. The external diameter of MWCNTs was about $40 \mathrm{~nm}$.

Research were carried out for epoxy adhesive Epidian 57 with PAC hardener, supplied by CIECH Sarzyna S.A Poland.

Static strength tests were conducted by the T-peel test for the specimens presented in Fig. 1. On the other hand, fatigue tests were conducted with the use of the specimens presented in Fig. 2. The adherends for both specimen variants were made of 2024-T3 aluminium alloy. A variety of methods of surface preparation were used prior to bonding process. The preferred method of preparing the surface for all of the variants was sand blasting; however, sand blasting caused bending in the case of the sheet metal used for the static strength tests. As a result, surfaces of these samples were ground, with the use of a non-woven fabric grinding wheel on a mandrel. The surfaces of the adherends used in the fatigue tests were sand blasted with aloxite $95 \mathrm{~A}$ under the following conditions: grain size $w z=0.27 \mathrm{~mm}$, air pressure $p=(0.8 \pm 0.1) \mathrm{MPa}$, and blasting time $t=60 \mathrm{~s}$.
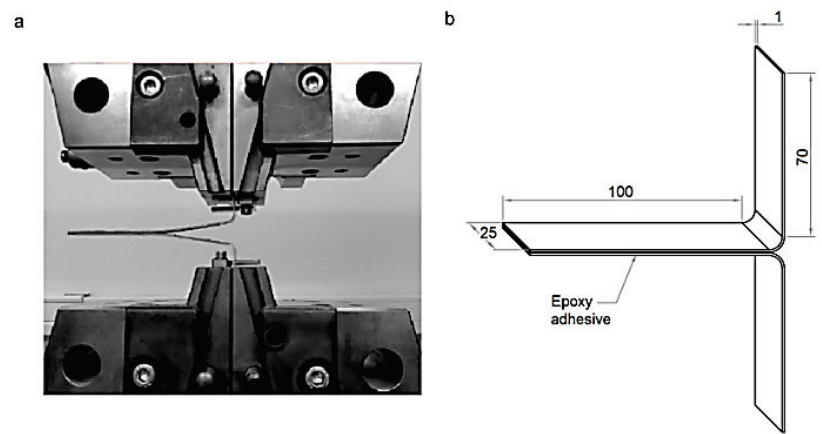

Figure 1 A joint specimen mounted on the testing machine (a) and dimensions (b) of sample used in static T-peel testing

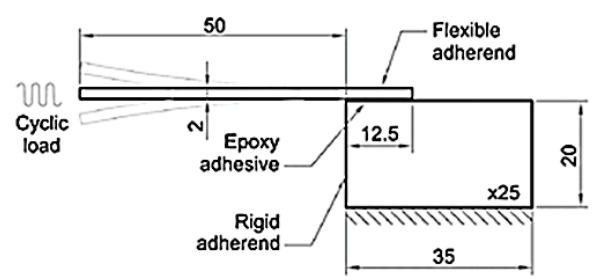

Figure 2 Dimensions of a sample used in peel fatigue strength testing 
The adhesive compositions with MWCNTs were prepared in the following sequential stages:

- the epoxy adhesive was heated up to $50{ }^{\circ} \mathrm{C}$ in order to reduce its viscosity

- the purified MWCNTs were added to the epoxy resins

- high-speed mechanical and ultrasonic mixing of the resin with the nanofiller was carried out at a constant temperature of $50{ }^{\circ} \mathrm{C}$

- after cooling, the right amount of hardener was added and mixed mechanically

The hardening process of the adhesive-bonded joints lasted $24 \mathrm{~h}$ at room temperature $\left(20 \pm 3{ }^{\circ} \mathrm{C}\right)$ under a constant pressure of $0.1 \mathrm{MPa}$ applied to the joint area. In result the thickness of adhesive layer was about $0.1 \mathrm{~mm}$.

The fatigue strength tests were applied to the specimens according to the following variants:

- variant E_neat: to glue the specimens, the Epidian 57 adhesive composition was used with PAC hardener (proportion: 80 parts by weight of the hardener per 100 parts by weight of the resin)

- variant E+0.5\%MWCNT: to the composition described above, 0.5 wt.\% of the filler was added in the form MWCNTs

- variant $\mathrm{E}+1 \% \mathrm{MWCNT}$ : analogical variant as above but $1 \mathrm{wt} . \%$ of the filler was added to epoxy adhesive

- variant $\mathrm{E}+1.5 \% \mathrm{MWCNT}$ : analogical variant with yet another content of the filler: $1.5 \mathrm{wt} . \%$

The static strength test that was done with the use of the T-peel test method was conducted on a Zwick Z100 machine with a displacement rate of $10 \mathrm{~mm} / \mathrm{min}$ at room temperature. Two values were recorded for every sample, namely peak load/force to initiate failure and average peeling force. Four repetitions were done for each variant. Fatigue tests were conducted with the use of the original methodology developed by the authors, which is a convenient and relatively fast high-cycle fatigue strength test method for testing the peeling of adhesive joints at a resonance frequency of specimen. Fatigue tests system is presented in Fig. 3.

The tests were done on the vibration test system TiraVib TV 50350 LS 120 which consists of: the vibration exciter S 50350-120, the amplifier A1 011004.

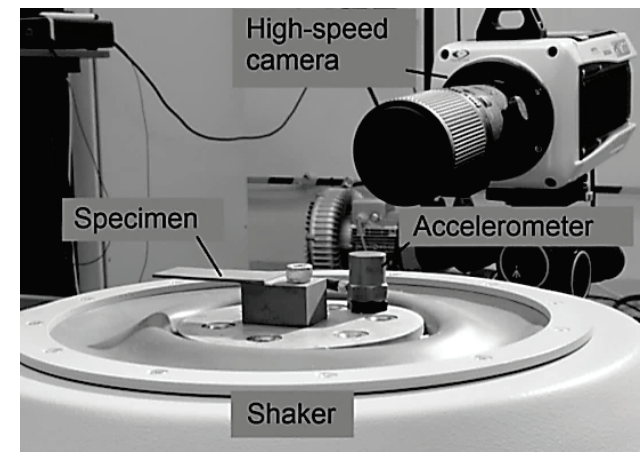

Figure 3 Photo of the fatigue tests system

The objective of the research was to evaluate the impact of the above-described type of epoxy adhesive filled by MWCNT on the fatigue strength of an adhesive joint subjected to peel loading at the limit number of cycles $2 \times 10^{6}$. The performed tests were in fact the accelerated measurements of fatigue strength in a symmetrical (oscillating) stress cycle.

Specimens for each variant were subjected to resonance vibrations at four different amplitude levels. The number of cycles was counted up to the point when it was no longer possible to maintain the vibrations of the specimen at a given amplitude level, which was the evidence of destruction. For every level, the tests were repeated four times. The lowest level of the dynamic load was the value at which the specimen did not fail after being loaded by $2 \times 10^{6}$ cycles.

The amplitude of the end of the flexible adherend was measured using a high speed camera Phantom v711 (Fig. $3)$. This amplitude value was correlated to the maximum normal stress in the adhesive joint by FEM analysis.

\section{Results and discussion}

The results of T-peel static strength tests are listed in table 1 . The experiment shows that for every joint variant with the nanofiller, the value of the peak load is significantly greater in comparison to the basic variant without filler. Meanwhile, this tendency is reversed in later stages where the average peeling force is greater for the basic variant ( $\mathrm{B}$ neat and $\mathrm{E}$ neat).

Table 1 Values of peak load and average peeling force of the T-peel test for concerned MWCNT content in the adhesive composition

\begin{tabular}{|l|c|c|}
\hline \multicolumn{1}{|c|}{ Variant of joint } & Peak load $(N)(\mathrm{SD})$ & $\begin{array}{c}\text { Average peeling } \\
\text { force }(N)(\mathrm{SD})\end{array}$ \\
\hline E_neat & $87.36(9.11)$ & $46.27(4.65)$ \\
\hline E+0.5\%MWCNT & $106.41(13.39)$ & $35.76(7.26)$ \\
\hline E+1\%MWCNT & $101.75(16.48)$ & $34.12(8.91)$ \\
\hline E+1.5\%MWCNT & $92.99(15.61)$ & $29.31(7.83)$ \\
\hline
\end{tabular}

The graphs plotted during T-peel tests for variants with and without nanofiller were compared (Fig. 4). The differences in the shape of the curves may suggest that adding nanofiller in the form of MWCNT has an impact on the increase in the stiffness of adhesive composition.

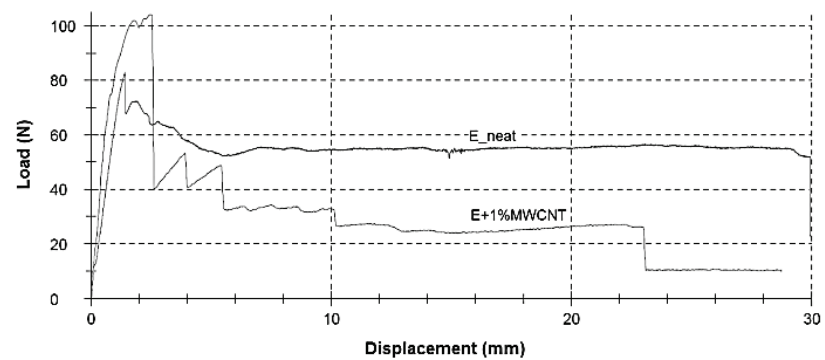

Figure 4 Comparison of load-displacement curves from T-peel test for variants $\mathrm{E} \_$neat and $\mathrm{E}+1 \% \mathrm{MWCNT}$

Analysis of fracture surfaces from static tests (Fig. 5) reveal that properly every variant shows cohesive failure in the front region of the joint. The further from the front of the joint, the more the condition varies depending on the variant. Characteristic for the basic variant is domination of cohesive failure, while the variant with adhesive nanofillers demonstrates adhesive failure everywhere besides the face.

When conducting fatigue strength tests, it was observed that the value of the resonance frequency of the specimen is dependent on degree of joint fatigue failure. 
Two stages can be differentiated. During the first stage, the value of the resonance frequency decreases slowly, which is related to the fatigue of the face of joint. In the final stage, there is quick decrease in resonance frequency prior to failure until it is impossible to maintain the vibrations at constant amplitude. At this stage, the joint is destroyed to such a degree that even when small force is applied, the joint will split.

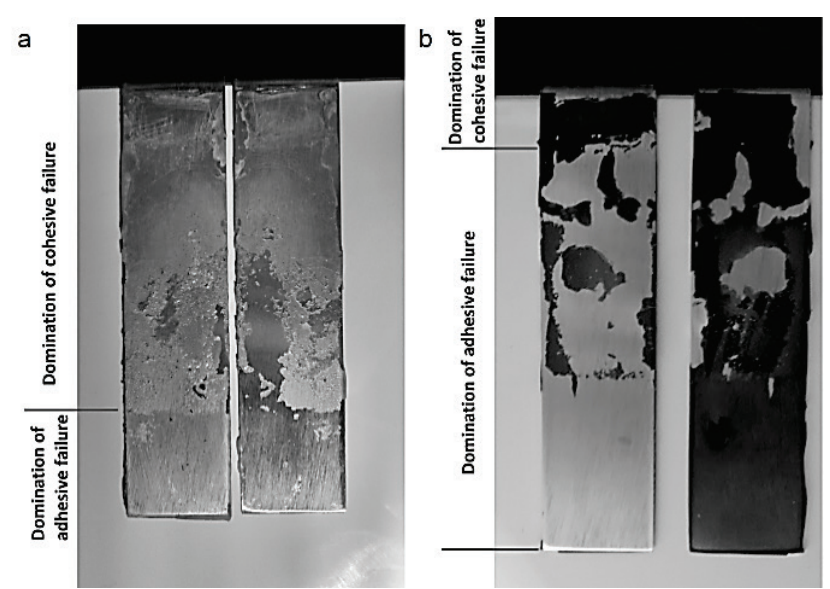

Figure 5 Examples of fracture surfaces from T-peel tests for basic (a) and filled (b) variants

The results of the fatigue strength tests show that it is possible to improve the fatigue properties of adhesive joints thanks to the use of MWCNTs as fillers for epoxy adhesives in every of considered amounts of MWCNTs.

Figs. $6 \div 8$ demonstrate the comparison of the fatigue curves for the basic variants and those with nanofillers.

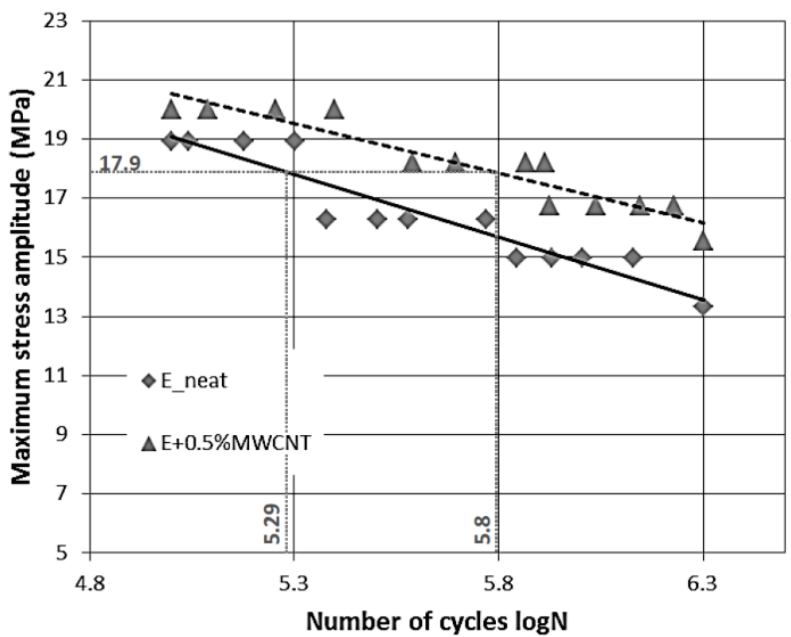

Figure 6 Comparison of fatigue curves neat and filled by $0.5 \mathrm{wt} . \%$ variants

In the best results for adhesive composition filled by 1 wt. $\%$ MWCNTs, the fatigue strength increased from 12.43 to $16.04 \mathrm{MPa}$ (an increase by $28.9 \%$ ) compared to E_neat variant (Fig. 6). For other variants filled by MWCNT worse results were obtained, but there is still increase of fatigue strength (Fig. 6, 8).

The results of fatigue tests confirmed that it is possible to significantly improve the fatigue lifetime; for example, in the case of E+1\%MWCNT variant at the stress amplitude of $17.9 \mathrm{MPa}$, a more than fourfold increase in the fatigue lifetime was obtained from 199000 to 1150000 cycles (an increase of $477.2 \%$ ).
Comparison of the results of fatigue strength and fatigue lifetime (at the stress amplitude of $17.9 \mathrm{MPa}$ ) is presented in Fig. 9.

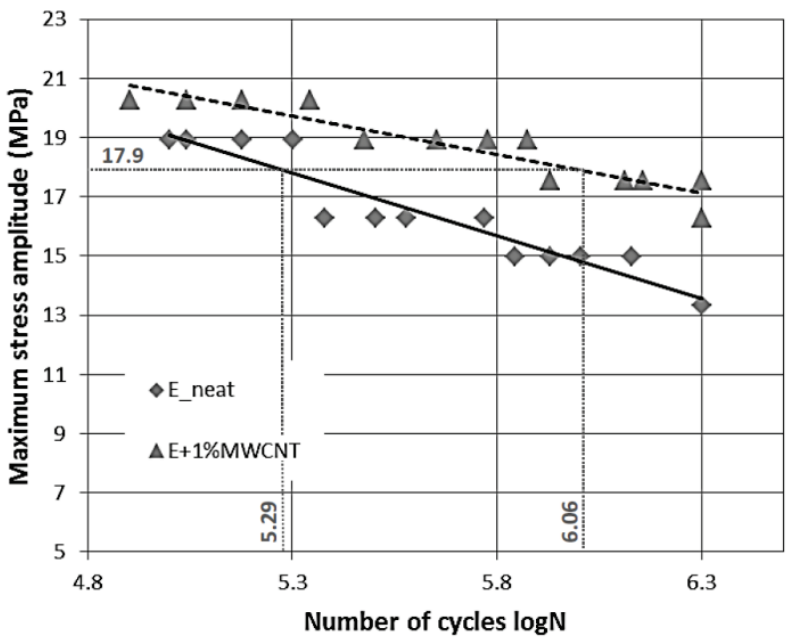

Figure 7 Comparison of fatigue curves neat and filled by $1 \mathrm{wt} . \%$ variants

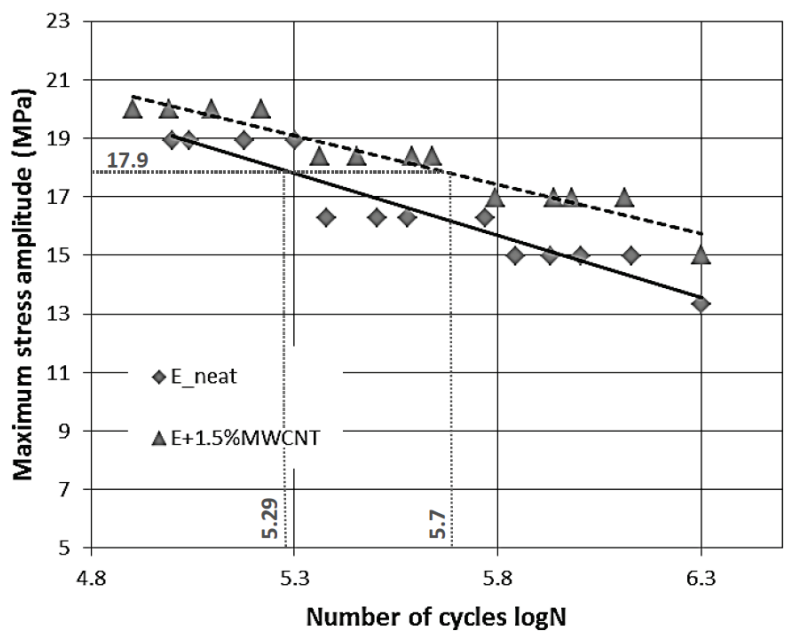

Figure 8 Comparison of fatigue curves neat and filled by 1.5 wt. $\%$ variants

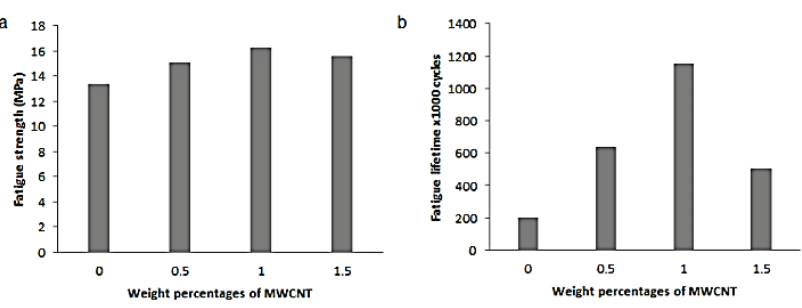

Figure 9 Adhesive joints fatigue strength (a) and fatigue lifetime (b) depending on the MWCNT content
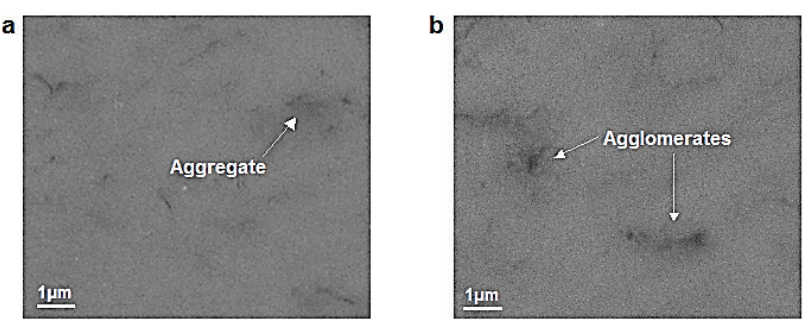

Figure 10 SEM image of 1 wt.\% MWCNT (a) and 1.5 wt.\% MWCNT (b) in Epidian 57/PAC epoxy adhesive 
Fig. 10a presents SEM micrograph of cured Epidian57/PAC adhesive filled by $1 \mathrm{wt} . \%$ MWCNTs with visible carbon nanotubes.

In every case of amount of filler to increase both strength and fatigue life were showed. Best result was clearly demonstrated for the content of $1 \mathrm{wt} . \%$ MWCNTs and for the greater content slightly lower performance was obtained. This phenomenon can be explained by the greater tendency to forming agglomerates of carbon nanotubes with higher content, Fig. 10b shows visible agglomerates of the cured epoxy adhesive filled by 1.5 wt.\% MWCNTs.

The possibility of improving the strength properties at variable cyclic loads by means of nanofillers, in this case the MWCNTs, was confirmed.

Barber et al. [13] explained that the mechanism of improvement of some mechanical properties by means of MWCNTs in epoxy matrix is related to the phenomenon of CNTs, whose addition provides an additional source of energy absorption. Gojny et al. [14] and Singh et al. [15] revealed that the Multi-walled nanotubes absorb more energy, which is dissipated within the area of nanotubes and takes more time to penetrate the specimen area.

It is believed that the randomly oriented MWCNTs are responsible for such high resistance to separation of the MWCNT composites $[16,17]$. The increased number of features on the surface (ridges) gives rise to a greater area for the absorption of the fracture energy, thus giving rise to higher values of toughness. Inclusion of the organical MWCNT gives rise to mechanical reinforcement at the molecular level. Further the enhanced contact between the fillers and the resin results in better bonding, thus restricting the crack propagation path [17].

The authors of the paper [13] focused on the measurement of a single MWCNT and the strength of the polymer matrix joint. They proved that the value of separation stress is relatively high, which indicates the existence of both chemical and physical interactions in the bonding model. This confirms that the above-mentioned mechanisms of nanotube pull-out and crack bridging are effective and provide improvements of fatigue strength.

\section{Conclusion}

This paper offers an experimental insight into the fatigue strength properties of three epoxy adhesive polymers containing MWCNTs. The results of the experiment clearly suggest that the addition of MWCNT fillers to epoxy adhesives makes it possible to improve the properties of reinforced epoxy adhesives such as fatigue strength properties and their fatigue lifetimes.

Despite the fact that the use of CNTs is still not a common practice, because of the high cost of fabrication, the ongoing research into less expensive manufacturing techniques lets us assume that this type of material will be widely used in the future to improve the strength properties of bonded structural joints. The results of the research presented in this paper show that nanotechnology can contribute to the improvement and, therefore, more common use of adhesive-bonded structures.

\section{$5 \quad$ References}

[1] Pilawka, R.; Gorący, K. Investigation of curing process for epoxy-isocyanate compositions. // Kompozyty. 11 (2011), pp. 44-48.

[2] Yim, B.; Kim, J. Characteristics of Isotropically Conductive Adhesive (ICA) Filled with Carbon Nanotubes (CNTs) and Low-Melting-Point Alloy Fillers. // Materials Transactions. 12 (2010), 2329-2331. https://doi.org/10.2320/matertrans.M2010301

[3] Gojny, F.; Wichmann, M.; Fiedler, B.; Bauhofer, W.; Schulte, K. Influence of nano-modification on the mechanical and electrical properties of conventional fibrereinforced composites. // Composites: Part A. 36 (2005), pp. $1525-1535$. https://doi.org/10.1016/i.compositesa.2005.02.007

[4] Wernik, J.; Meguid, S. On the mechanical characterization of carbon nanotube reinforced epoxy adhesives. // Materials and Design. 59 (2014), pp. 19-32. https://doi.org/10.1016/j.matdes.2014.02.034

[5] Gkikas, G.; Sioulas, D.; Lekatou, A.; Barkoula, N.; Paipetis, A. Enhanced bonded aircraft repair using nanomodified adhesives. // Materials and Design. 41 (2012), pp. 394-402. https://doi.org/10.1016/j.matdes.2012.04.052

[6] Liu, H.; Wang, X.; Fang, P.; Qi, X.; Pan, C. Functionalization of multiwalled carbon nanotubes grafted with self-generated functional groups and their polyamide 6 composites. // Carbon. 48 (2010), pp. 721-729. https://doi.org/10.1016/j.carbon.2009.10.018

[7] Sahoo, N.; Cheng, H.; Cai, J.; Li I.; Chan, S.; Zhao, J. Improvement of mechanical and thermal properties of carbon nanotube composites through nanotube functionalization and processing methods. // Materials Chemistryand Physics. 117 (2009), pp. 313-320. https://doi.org/10.1016/j.matchemphys.2009.06.007

[8] Packham, R. Pretreatment of aluminum: topography, surface chemistry and adhesive bond durability. // International Journal of Adhesion and Adhesives 15 (1995), pp. 61-71. DOI: 10.1016/0143-7496(95)98739-9

[9] Elkadi, H.; Ellyin, F. Effect of stress ratio on the fatigue of unidirectional glass- fiber epoxy composite laminate. // Composites 25 (1994), pp. 917-924. https://doi.org/10.1016/0010-4361(94)90107-4

[10] Mandell, J.; Meier. U. Effects of stress ratio, frequency, and loading time on the tensile fatigue of glass-reinforced epoxy, long-term behavior of composites. // Symposium, Williamsburg, VA, USA (1983), pp. 55-77.

[11] Underhill, P.; Du Quesnay, D. The dependence of the fatigue life of adhesive joints on surface preparation. // International Journal of Adhesion and Adhesives. 26 (2006), pp. 62-66 https://doi.org/10.1016/j.jjadhadh.2005.03.006

[12] Crocombe, A.; Richardson, G. Assessing stress state and mean load effects on the fatigue response of adhesively bonded joints. // International Journal of Adhesion and Adhesives. 19 (1999), pp. 19-27. https://doi.org/10.1016/S0143-7496(98)00049-9

[13] Barber, A.; Cohen, S.; Wagner, H. Measurement of carbon nanotube-polymer interfacial strength. // Applied Physics Letters. 23 (2003), pp. 4140-4143. https://doi.org/10.1063/1.1579568

[14] Gojny, F.; Wichmann, M.; Fiedler, B.; Schulte, K. Influence of different carbon nanotubes on the mechanical properties of epoxy matrix composites-A comparative study. // Composites Science and Technology. 65 (2005), pp. 2300-2313. https://doi.org/10.1016/j.compscitech.2005.04.021

[15] Singh, S., Srivastava, V., Prakash, R. Influences of carbon nanofillers on mechanical performance of epoxy resin polymer. // Applied Nanoscience. 5 (2015), pp. 305-313. 
https://doi.org/10.1007/s13204-014-0319-0

[16] Ganguli, S.; Aglan, H.; Dean, D. Microstructural origin of strength and toughness of epoxy nanocomposites. // Journal of Elastomers and Plastics. 37 (2005), pp. 19-35. https://doi.org/10.1177/0095244305045927

[17] Hedia, H.; Allie, L.; Ganguli, S.; Aglan, H. The influence of nanoadhesives on the tensile properties and Mode-I fracture toughness of bonded joints. // Engineering Fracture Mechanics. 73 (2006), pp. 1826-1832.

https://doi.org/10.1016/j.engfracmech.2006.02.013

\section{Author's address}

\section{Andrzej Kubit, PhD}

Rzeszow University of Science and Technology,

The Faculty of Mechanical Engineering and Aeronautics, al. Powstańców Warszawy 8, 35-959 Rzeszów, Poland akubit@prz.edu.pl 